\title{
Temporal Changes in Environmental Health Risks and Socio-Psychological Status in Areas Affected by the 2011 Tsunami in Ishinomaki, Japan
}

\author{
Kohei Makita ${ }^{1}$, Kazuto Inoshita ${ }^{1}$, Taishi Kayano ${ }^{1}$, Kei Uenoyama ${ }^{1}$, Katsuro Hagiwara ${ }^{1}$, Mitsuhiko Asakawa ${ }^{1}$, \\ Kenta Ogawa ${ }^{2}$, Shin'ya Kawamura ${ }^{3}$, Jun Noda ${ }^{1}$, Koichiro Sera ${ }^{4}$, Hitoshi Sasaki ${ }^{2}$, Nobutake Nakatani ${ }^{2}$, Hidetoshi \\ Higuchi $^{1}$, Naohito Ishikawa ${ }^{5}$, Hidetomo Iwano ${ }^{1} \&$ Yutaka Tamura $^{1}$ \\ ${ }^{1}$ School of Veterinary Medicine, Rakuno Gakuen University, 582 Bunkyodai Midorimachi, Ebetsu, Japan \\ 2 College of Agriculture, Food and Environmental Sciences, Rakuno Gakuen University, Bunkyodai \\ Midorimachi, Ebetsu, Japan \\ ${ }^{3}$ Department of Human Sciences, Graduate School of Letters, Hokkaido University, Kita-ku, Sapporo, Japan \\ ${ }^{4}$ Cyclotron Research Center, Iwate Medical University, Takizawa, Iwate, Japan \\ ${ }^{5}$ Action for Peace, Capability and Sustainability (APCAS), Colombo, Sri Lanka \\ Correspondence: Kohei Makita, School of Veterinary Medicine, Rakuno Gakuen University, Ebetsu 069-8501, \\ Japan. Tel: 81-11-388-4761. E-mail: kmakita@rakuno.ac.jp
}

Received: August 5, 2013 Accepted: October 22, 2013 Online Published: November 4, 2013

doi:10.5539/ep.v3n1p1 URL: http://dx.doi.org/10.5539/ep.v3n1p1

\begin{abstract}
On March 11 2011, a tsunami caused by a magnitude 9.0 earthquake devastated the northeastern coast of Honshu, Japan.The present study was conducted to assess environmental health risks of the areas affected and socio-psychological status of the dislocated people in Ishinomaki.

Samples of sludge, water, flies and rodents were collected in 20 urban neighborhood associations affected by the tsunami in July and August 2011, and in August 2012. A socio-psychological survey was conducted in two urban and one rural temporary housing complexes in 2012. Animal feed concentrates and fish from damaged factories were scattered along the coast which caused a strong odor and great number of flies. Removal of fish and feed along with spraying insecticides reduced the odor and the number of flies by August 2011. The sludge and water samples contained potentially hazardous bacteria, but none were highly pathogenic. Heavy metals in sludge were not in alarming quantities. A rodent was captured in one unit in August 2011, and monitoring in two units found that the $\log$ number of rodents captured increased significantly over time (slope $=0.08, p=0.005$ ). In temporary housing complexes, those who originally lived in rural fishing villages wished to return to their homes more $(64.2 \%, 9 / 14)$ than in urban areas $(30.6 \%, 11 / 36, p=0.06)$. Risk factors for depression included absence of friends $(p=0.011)$ or trusted person to counsel in the housing complexes $(p=0.003)$ and illness of the respondent or a family member $(p=0.003)$. In conclusion, overall environmental health risk was acceptable for living, and monitoring of rodents population was recommended. In addition, psychological and economical support was needed for evacuees in temporary housing complexes.
\end{abstract}

Keywords: The 2011 Tohoku-Oki Tsunami, earthquake, environmental health risk assessment, insect infestation, heavy metals, mental stress, rodent infestation, disaster

\section{Introduction}

A magnitude 9.0 earthquake occurred offshore of the northeast coast of Honshu, Japan at 14: $46 \mathrm{pm}$ on March 11, 2011, generating a devastating tsunami that destroyed many towns and villages near the seashore in Iwate, Miyagi and Fukushima prefectures (Shibahara, 2011). The earthquake was named the 2011 Off the Pacific Coast of Tohoku Earthquake by the Japan Meteorological Agency (JMA, 2011) and the Japanese cabinet named the collective disasters caused by this earthquake the Great East Japan Earthquake (PMJHC, 2011). The total number of deaths caused by the disaster totaled 15883, and 2681 people were still missing by April 1, 2013 (NPA, 2013). The coastal city of Ishinomaki in Miyagi Prefecture (Figure 1) was severely affected by the tsunami, which flooded about $13 \%$ of the city where $70 \%$ of the population lived (Ueda, Hanzawa, Shibata, \& 
Suzuki, 2012). Table 1 summarizes the damage and health problems experienced by inhabitants of Ishinomaki. The large scale tsunami warning was announced at 14: $49 \mathrm{pm}$ and at $15: 26 \mathrm{pm}$, more than $8.6 \mathrm{~m}$ of tsunami reached to Ishinomaki (JMA, 2011). In the affected areas by the tsunami overall in Japan, $62.6 \%$ of people started evacuation before the large scale tsunami arrived, $10.6 \%$ after arrived, and $26.8 \%$ did not evacuate, based on a study with 4,421 respondents (MLITT, 2011). Ishinomaki lost the lives of 3506 people, which accounted for $22 \%$ of total deaths in Japan (Table 1). The tsunami necessitated the evacuation of $31.6 \%$ of the city population (peak on March 17, 2011) to disaster shelters. Immediately after the tsunami, the Self Defense Force of Japan, together with foreign rescue teams including US military forces, began rescuing people trapped in debris, searched for those who were missing or presumed dead and restored life lines to the affected areas. There were domestic and international financial and material donations through United Nations, Red Cross and other NGOs. Volunteers and NPOs also played critical roles in restoring the city, providing meals and caring for evacuees. Evacuees were encouraged to move to rental flats and rapidly constructed temporary housing complexes, and all disaster shelters were closed by October 11, 2011, 7 months after the earthquake. The supplying period of the temporary houses had been for two years but was extended another year until 2014 (Miyagi Prefecture, 2012). The government is reclaiming uplands for relocation from coastal residential areas and creating employment opportunities (Reconstruction Agency, 2013). The other political supports include partial financial supports for lost and damaged houses, exemption of tax and interests for a double loan (a loan for new house construction in addition to the remaining loan), and supports for families with children and those who lost employment, and mental and physical health (Miyagi Prefecture, 2012).

The clinical phases of natural disasters can be classified as follows (Aghababian \& Teuscher, 1992; Kouadio et al., 2012): phase 1 (impact phase, 0-4 days), initial treatment of disaster-related injuries is provided; phase 2 (post-impact phase, 4 days to 4 weeks), the first waves of air-, food-, and/or water-borne infectious diseases emerge as a substantial portion of the population is displaced into unplanned and overcrowded shelters; and phase 3 (recovery phase, after 4 weeks), infections with long incubation periods or latent types can become clinically apparent.

In Ishinomaki, in the phase 1, dehydration, vomiting and diarrhea were frequently observed due to lack of clean water and hygiene. In the phase 2, seven cases of tetanus, two cases of legionellosis, small outbreaks of diarrhea, respiratory diseases and deep vein thrombosis resulted from dehydration and restricted movement in crowded disaster shelters were reported (Table 1). There were 259 disaster shelters in Ishinomaki. In the tsunami-flooded areas, shelters were very crowded with approximately 1000 evacuees per shelter. Most of the shelters provided 10 square feet per person for many weeks and at most 20 square feet per person for several months (Picture 1) (Ueda et al., 2012).

While public health authorities concentrated on the health status and treatment of evacuees in the disaster shelters, environmental hygiene received little focus. Poor environmental hygiene can be a source of infectious and non-infectious diseases not only for evacuees in shelters, but also for those who return to damaged homes or move into rented rooms or temporary housing complexes (Picture 2). The most frequently reported infectious diseases associated with a tsunami and floods in the world are diarrhea, hepatitis A and E, acute respiratory infections (ARIs), measles, meningitis, tetanus, cholera, and leptospirosis (Kouadio et al., 2012). Although international data are scarce, levels of heavy metals were increased by the tsunamis in 2011 in Japan (Baba \& Sera, 2012) and in 2004 in India (Ranjan, Ramanathan, Singh, \& Chidambaram, 2008) and such contaminants in soil might pose public health risks unless long-term exposure and internal accumulation are prevented. The present study assesses environmental health risks due to microbiological agents, wildlife and chemical hazards in the areas of Ishinomaki affected by the tsunami to provide information that can be used to plan reconstruction policies. As a risk is assessed by the combination of probability of occurrence of a scenario that will affect humans and the size of the impact (Vose, 2008), we also conducted a sociological survey to assess the desires of evacuees in temporary housing complexes to return the areas affected by the tsunami. The mental health status of the residents was also surveyed to provide adequate and timely policy support.

The locations and needs of evacuees, the progress of restoration, and environmental hygiene obviously changed over the course of the study period. The present paper describes the temporal dynamics of general observations, entomology, wildlife, microbiology, chemistry and socio-psychology in the areas affected by the tsunami in Ishinomaki. 
Table 1. Damages in Ishinomaki, Miyagi caused by the Great East Japan Earthquake

\begin{tabular}{|c|c|c|}
\hline Damage & Description of damage & Source \\
\hline Deaths: 3506 & $\begin{array}{l}\text { Greatest amongst townships in Japan, } 2.2 \% \\
\text { of city population, } 22 \% \text { of total deaths }\end{array}$ & $\begin{array}{l}\text { (MIAC, 2011) } \\
\text { (Ishinomaki City, 2013) }\end{array}$ \\
\hline Missing: 453 & $16.9 \%$ of total missing & (Ishinomaki City, 2013) \\
\hline $\begin{array}{l}\text { Population lived in the } \\
\text { flooded areas: } 112000\end{array}$ & Greatest amongst townships in Japan & (Statistics Bureau, 2011) \\
\hline $\begin{array}{l}\text { People dislocated to disaster } \\
\text { shelters: } 50758\end{array}$ & $\begin{array}{l}\text { Peak on March 17, } 2011 \\
31.6 \% \text { of the city population }\end{array}$ & (Statistics Bureau, 2011) \\
\hline $\begin{array}{l}\text { Number of disaster shelters: } \\
259\end{array}$ & $\begin{array}{l}\text { Peak on March 18, 2011. Public shelters } 99 \\
\text { and the rest voluntarily set up }\end{array}$ & Ishinomaki City Council \\
\hline \multirow{6}{*}{$\begin{array}{l}\text { Health problems among } \\
\text { evacuees in the shelters in } \\
\text { Ishinomaki }\end{array}$} & Impact phase: & \\
\hline & Dehydration, vomiting and diarrhea & (Ueda et al., 2012) \\
\hline & Post-impact phase: & \\
\hline & Tetanus 7 cases, legionellosis 2 cases & (IASR, 2011a) \\
\hline & $\begin{array}{l}\text { Gastro-intestinal diseases } 92 \text {, influenza } 15 \text {, } \\
\text { respiratory diseases } 788 \text {, rash } 5 \text {, scabies } 6 \\
\text { and injury } 2 \text { cases }\end{array}$ & (IDSC, 2012) \\
\hline & $\begin{array}{l}\text { Deep vein thrombosis, } 200 \text { times higher } \\
\text { incidence }(2.2 \%)\end{array}$ & (Ueda et al., 2012) \\
\hline
\end{tabular}

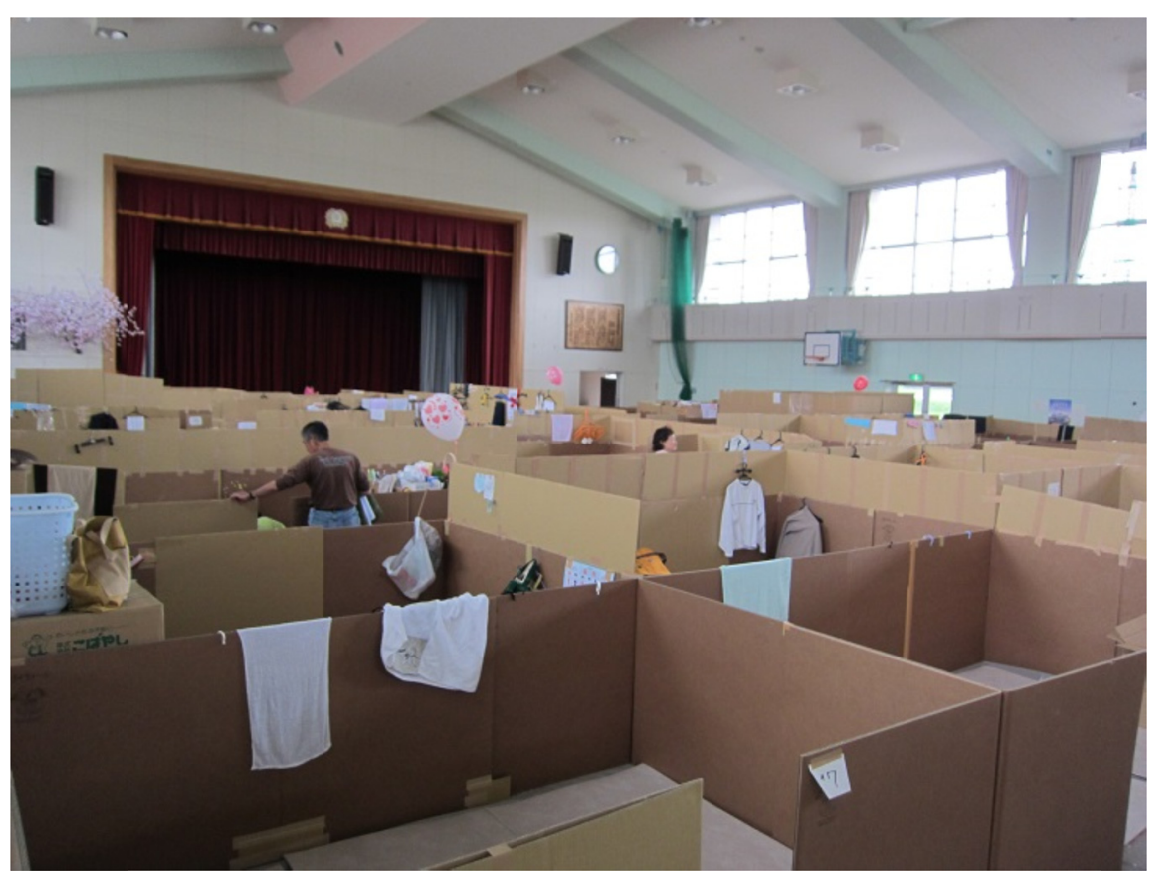

Picture 1. A disaster shelter set up in a gym of a primary school (taken on May 27, 2011) 


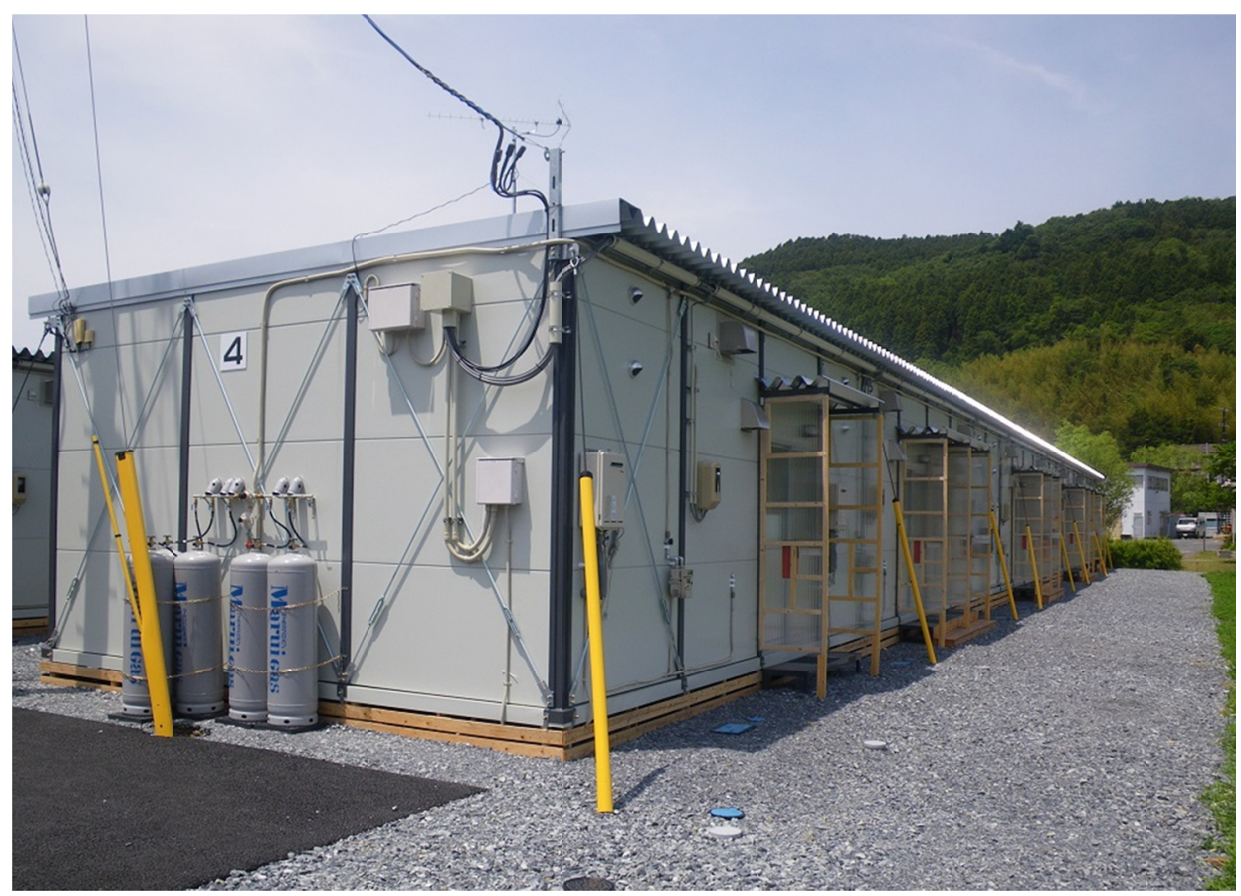

Picture 2. A house in Kaisei temporary housing complex, Ishinomaki

Note: Each entrance on the right side of the house belong to each family (taken in June, 2011).

\section{Study Sites}

The present study assessed the environmental health risk of areas affected by the tsunami and the socio-psychological status of individuals who were displaced to temporary housing complexes. Environmental health risk was assessed in an 11-km strip of coastline with $2 \mathrm{~km}$ width towards inland of Ishinomaki, Miyagi. The socio-psychological study was conducted in one rural (Aikawa) and two urban (Kaisei and Watanoha) temporary housing complexes (Figure 1). We define urban temporary housing complex as the complex located within or peripheral of densely populated areas where receives evacuees from urban areas of Ishinomaki City, whereas rural temporary housing complex as the complex located in a rural area where urbanisation has not yet started. Kaisei temporary housing complex (t2, Figure 1) falls in a category 'peri-urban' in a development context while Watanoha (t3) is located in urban area (Makita et al., 2010). Kaisei temporary housing complex was constructed in a large park which was not inundated. Watanoha complex was located in the flooded area within proximity of severely damaged areas. Aikawa (t1) was located on a hill of a fisherman village, where the areas along the coast were severely affected. The dominant industry around the urban temporary housing complexes was services, while that of Aikawa was fishery. 


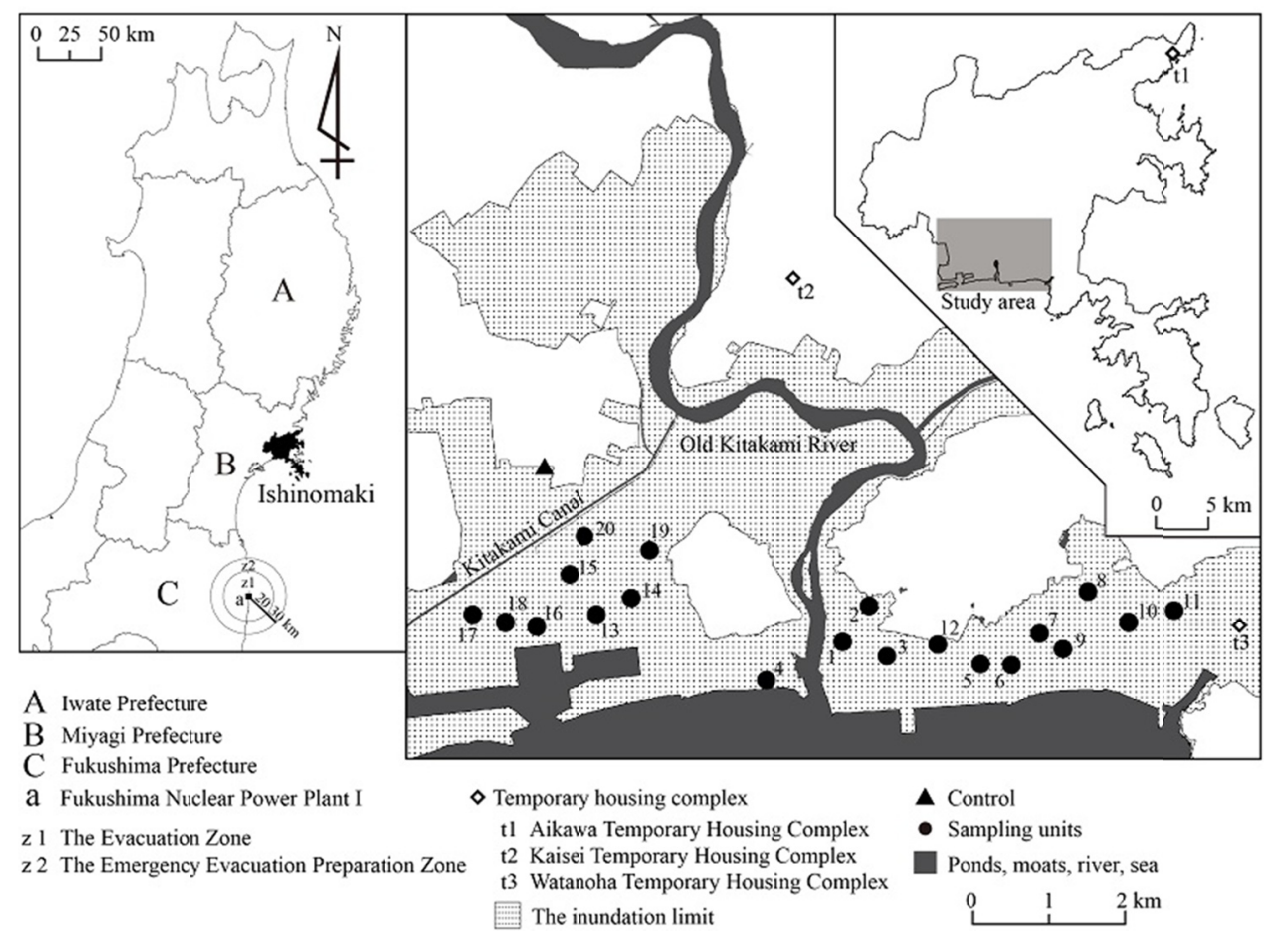

Figure 1. Maps showing the study sites.

Note: The left panel shows Tohoku Region, the northern part of the main land of Japan, with the locations of Iwate, Miyagi and Fukushima Prefectures, Ishinomaki City and Fukushima Nuclear Power Plant I. Right panel shows the locations of environmental study area and Aikawa Temporary Housing Complex (t1). Central panel shows closer view of the study area. Black dots represent 20 sampling units selected (neighborhood associations), and Kaisei (t2) and Watanoha (t3) Temporary Housing Complexes.

Ishinomaki has a cool climate with a mean annual temperature $11.6{ }^{\circ} \mathrm{C}$. The annual rainfall in 2012 was 954.5 mm (JMA, 2013). The annual mean temperature, maximum temperature in summer (July), and minimum temperature in winter (January) in 2012 were $11.6{ }^{\circ} \mathrm{C}, 32.0^{\circ} \mathrm{C}$, and $-8.3{ }^{\circ} \mathrm{C}$, respectively.

\section{Materials and Methods}

\subsection{Sampling Framework for Environmental Health Risk Assessment}

A stratified random sampling of chonai-kai (neighborhood associations), the smallest administrative units in Japan, was performed in the study areas described above. The study areas were divided into two groups: east and west of the Old Kitakami River. Minamihama-cho, Kadowaki-cho and Hibarino-cho, the flat areas located at the corner of the west bank of the Old Kitakami River and the ocean, were excluded, as all houses in these areas were completely lost or destroyed and no one lived there. Twenty of the 87 chonai-kai units were selected (Figure 1), among which 12 and eight were located in the western and eastern strata, respectively. The sample size was determined based on a formula to estimate prevalence.

$$
N=\frac{1.96^{2} \times P_{\exp } \times\left(1-P_{\text {exp }}\right)}{d^{2}}
$$

Where $N$ is a sample size representative of an infinite population, $P_{\text {exp }}$ is an expected prevalence, and $d$ is required precision (Thrusfield, 2005). $P_{\exp }$ was set to be 3.6\% targeting pathogenic Vibrio cholerae, referring prevalence in river water at estuary in Kanagawa Prefecture (toxin producing $V$. cholerae $\mathrm{O} 1$ and non-O1 $V$. cholerae were isolated from 30 and 513 (61.1\%) samples, respectively, out of 840 samples) between 1989 and 1995 (Yamai, Okitsu \& Katsube, 1998). The required precision was set to be $90 \%$. $N$ was calculated as 13.3, but in order to have a robust figure, the sample size was increased by $50 \%$ and determined to be 20 .

\subsection{Entomological, Biological, and Chemical Sampling}

Sludge and water were collected in a 500 $\mathrm{ml}$ light-resistant glass bottle in the selected units in July and August 2011 and August 2012. Flies were sweep-sampled using $42 \mathrm{~cm}$ diameter sweeping net with $1 \mathrm{~m}$ shaft for bacteriological tests in five purposively selected units where the numbers of flies were subjectively judged to be 
great in July 2011. Flies were also captured using water traps with a few drops of surfactant in a yellow plastic container for 1 day and 1 night in one unit each strata where the number of flies was great. All the samples were chilled and packaged in Ishinomaki and sent to Rakuno Gakuen University (RGU) for morphological, microbiological, and chemical analyses.

Rodents were sampled in the 20 units in August 2011, using Sherman Traps (H. B. Sherman Traps Inc., FL, USA). Follow-up sampling was conducted at the unit 17 (Figure 1) in the western stratum, where a rodent was trapped in August 2011 (see Results), in November 2011 and in March and May 2012. In November 2012, sampling was conducted at the unit 17 again, and a grassland with a pine woods near the unit 9 (Figure 1), both of which were ecologically suitable habitats for rodents - proximity to water source such as canal and sea, secondary woods, and compiled debris. Collected rodents were euthanized in the field, chilled, and sent to RGU for microbiological tests.

\subsection{Microbiological Tests}

In 2011, bacteriological tests were performed on the sludge and water samples collected for total bacteria, enterobacteriaceae, Salmonella, spore-forming bacteria, Vibrio, and Aeromonas. Bacteriological follow-up in August 2012 comprised assessments of spore-forming bacteria.

Total bacteria, enterobacteriaceae, Salmonella, and spore-forming bacteria were counted in serially diluted samples of sludge and water. Total bacteria was counted after incubation on brain heart infusion agar in $5 \% \mathrm{CO}_{2}$ at $37^{\circ} \mathrm{C}$ for $24 \mathrm{~h}$. Enterobacteriaceae, which can indicate contamination with sewage or feces, were cultured on DHL agar at $37{ }^{\circ} \mathrm{C}$ for $24 \mathrm{~h}$. Salmonella, which is a common cause of severe food poisoning, was enriched using Hajna tetrathionate broth at $37{ }^{\circ} \mathrm{C}$ for $18 \mathrm{~h}$, left at ambient temperature at around $25{ }^{\circ} \mathrm{C}$ for 7 days, and inoculated onto Mannitol Lysine Cristal Violet Brilliant Green (MLCB) agar (Nissui, Tokyo, Japan) at $37{ }^{\circ} \mathrm{C}$ for $24 \mathrm{~h}$. Aerobic spore-forming bacteria were cultured on Trypticase soy agar (Becton, Dickinson and Company, MD, USA) supplemented with $5 \%$ sheep blood (5\% sheep blood agar) at $37{ }^{\circ} \mathrm{C}$ for $24 \mathrm{~h}$. Anaerobic spore-forming bacteria were cultured on $5 \%$ sheep blood agar anaerobically for $72 \mathrm{~h}$. Aerobic spore-forming bacteria were identified as Bacillus spp. and the anaerobic spore-forming bacteria were Clostridium spp. Bacillus spp. includes $B$. anthrax, which causes cutaneous and intestinal diseases, and $B$. cereus, which can cause food poisoning due to enterotoxin. Clostridium spp. includes $C$. tetanus, which causes tetanus after invading skin wounds, and C. perfringens, which causes food poisoning. C. perfringens isolated by anaerobic incubation on $10 \%$ egg yolk $\mathrm{CW}$ agar (Nissui) at $37{ }^{\circ} \mathrm{C}$ for $72 \mathrm{~h}$ was identified based on Nagler's reaction and inhibition by antiserum. Vibrio and Aeromonas can cause food poisoning and $V$. cholerae serogroups O1 biotype El Tor and O139 cause cholera, and they are frequently associated with sea foods in developed countries and contaminated water in developing countries (Sack, Sack, Naire \& Siddique, 2004). Sludge samples suspended in phosphate-buffered $2 \% \mathrm{NaCl}$ and water samples enriched with alkaline peptone broth at $37^{\circ} \mathrm{C}$ overnight were inoculated onto ES Vibrio agar plate (Eiken Chemical Co., Ltd., Tokyo, Japan) and incubated at $37{ }^{\circ} \mathrm{C}$ overnight to determine the presence of Vibrio and Aeromonas. Isolated colonies were pure cultured on ES Vibrio agar plate once again and passaged onto $2 \% \mathrm{NaCl}$ Trypticase soy agar. The biochemical characteristics of pure colonies were determined using TSI, LIM, and oxidase tests, and bacteria were identified using API20E (bioMérieux Inc., Durham, NC, USA). Bacteria that were identified as $V$. cholerae were tested for sero-groups $\mathrm{O} 1$ and $\mathrm{O} 139$, as well as the $c t x A$ virulence gene using PCR.

A pool of 10 flies sampled by sweeping in July 2011 was prepared for each of the five sites. These five pools were served for bacteria counting of total bacteria, enterobacteriaceae, and Salmonella.

Sludge samples were virologically tested for hepatitis E virus (HEV) and Norwalk-like virus (NLV), which are hazardous to human health and can be found in the environment. The HEVs associated with human hepatitis are classified into four genotypes ( $\mathrm{Lu}, \mathrm{Li} \&$ Hagedorn, 2006). Genotypes 1 and 2 cause waterborne outbreaks in developing countries and genotypes 3 and 4 are considered to be zoonotic and transmitted through the consumption of uncooked or undercooked contaminated meat (Mitsui et al., 2004; Wong, Purcell, Sreenivasan, Prasad, \& Pavri, 1980). Total RNA was extracted from sludge suspensions using QIAamp Viral RNA Kits (QIAGEN, Hilden, Germany). The HEV RNA of the 5 'terminal region of ORF1 was detected by semi-nested RT-PCR (Kanai et al., 2009) using the One Step RT-PCR Kit (Qiagen). NLVs which belong to the Caliciviridae family are major causes of acute nonbacterial gastroenteritis and a major public health concern. The NLV GI ORF1-ORF2 junction region was amplified by PCR using three forward primers for G1FF corresponding to nucleotides (nt) 5075 to 5097 in Norwalk/68, and the reverse primer, G1SKR (Kojima et al., 2002). The NLV GII ORF1-ORF2 junction region was also amplified by PCR using three forward primers for G2FB, corresponding to nt 4922 to 4941 in the Camberwell virus, and the reverse primer, G2SKR (Kojima et al., 2002). The RNA samples were reverse-transcribed using Transcriptor reverse transcriptase (Roche, Basel, Switzerland) and a random primer $(2.5 \mu \mathrm{M})$. All representative cDNA samples were then amplified by PCR. 
Apodemus speciosus trapped in August 2011 were tested using RT-nested PCR for Borna disease virus (BDV), which infects a wide range of mammals and causes immune-mediated, neurological Borna disease (BD), a disease that was originally discovered in horses (Staeheli, Sauder, Hausmann, Ehrensperger \& Schwemmle, 2000). Total RNA $(1 \mu \mathrm{g})$ isolated from the hippocampus of brain tissues using TRIzol (Invitrogen, Carlsbad, CA, USA) was reverse-transcribed using 200 units of SuperScript II reverse transcriptase (RT) (GIBCO BRL, Carlsbad, CA, USA) and random hexamers (100 ng). Borna disease virus-specific cDNAs corresponding to the BDV phosphoprotein (BDV-P) ORF were amplified by nested PCR as described elsewhere (Kishi et al., 1995).

\subsection{Chemical Analysis}

Water samples collected in June and August 2011 were passed through a syringe filter $(0.45 \mu \mathrm{m})$ and analyzed for anions and cations using DionexIC-20 (Thermo-Fisher Scientific, Waltham MA, USA) and PIA-1000 (Shimadzu, Kyoto, Japan) ion chromatographs.

Sludge samples were dried, homogenized, and analyzed for cadmium $(\mathrm{Cd})$, mercury $(\mathrm{Hg})$, lead $(\mathrm{Pb})$, and arsenic (As) using particle-induced X-ray emission (PIXE) at the Nishina Memorial Cyclotron Center (Iwate, Japan). The estimated detection limits for the toxic elements $\mathrm{Cd}, \mathrm{Hg}, \mathrm{Pb}$, and As were 20, 3, 3, and $1.4 \mathrm{ppm}$, respectively. A detailed description of the measurement setup is provided elsewhere (Sera \& Yanagisawa, 1992).

A control unit was selected from an unaffected residential area called Hebita (shown in Figure 1) as a reference for chemical analysis. The levels of all radioactive materials measured by the government surveillance remained below the standard levels established by the government and this topic was not further studied.

\subsection{Socio-Psychological Survey}

Findings of environmental damage and mental health that had been recorded in Excel data spread sheets by students, staff, and faculty members of RGU who had volunteered in Ishinomaki since May 2011 were qualitatively reviewed by the authors, and a summary was prepared in a participatory manner (Mariner \& Paskin, 2000). This database was created in Ishinomaki in order to accumulate information so that a new volunteer group arrived in the base camp can efficiently follow up the activities done by the previous group. Participatory appraisals (Mariner \& Paskin, 2000) were conducted in one rural and two urban temporary housing complexes and plans for future accommodations, current health status, stress, and the living environment of the residents were assessed in July 2012.

A questionnaire was designed based on the results of the participatory appraisals to understand the factors associated with reduced mental health in detail. K6 (Kessler et al., 2003) values were collected to screen for a serious mental illness (SMI) among residents in the temporary housing complexes. Respondents with K6 values $>13$ were considered to have SMI, referring a cut-off point suggested by Kessler et al. (2003). The Japanese translation of questions for K6, which was validated through the backtranslation procedure and with high value of the areas under receiver operating characteristic curves (AUCs): 0.94 (95\% confidence interval 0.88-0.99) (Furukawa, 2007), was used in the present study. The questionnaires were distributed to 50 households each at the two urban complexes and to all 44 households in the rural complex. To ensure anonymity, the respondents returned sealed questionnaires to RGU by mail.

\subsection{Statistical Analysis}

The number of rodents captured in a unit was $\log _{e}$-transformed, as a count follows Poisson distribution whose link for regression is logarithm, and a regression was performed with the explanatory valuable the month elapsed from occurrence of the tsunami when captured. The units where rodents were not captured were excluded from the analysis.

$\log _{10}$-transformed concentrations of bacteria were compared among samples of water and sludge that had been collected at different times using paired student $t$ tests. Means and confidence intervals were calculated in $\log _{10}$ scale. The prevalence of $C$. perfringens, Vibrio spp., and Aeromonas was compared using Chi-square test and Fisher's exact test was applied when at least one cell in $2 \times 2$ tables included an expected frequency below 5 .

Ion concentrations were log-normally distributed and $\log _{e}$-transformed data collected at different times were compared using paired Student's $t$ tests. The ratio of $\mathrm{Na}^{+}$and $\mathrm{Cl}^{-}$are useful for determining proximity to seawater (Yoshii et al., 2012) and the value of 0.56 for seawater was calculated based on data provided by Sverdrup, Johnson and Fleming (1961). The degree of proximity to seawater according to the ion composition of the samples is therefore expressed as a ratio of sample and seawater $\mathrm{Na}^{+} / \mathrm{Cl}^{-}$(a ratio of 1 suggests that the $\mathrm{Na}^{+} / \mathrm{Cl}^{-}$ values of the seawater and the sample are identical). Ratios were also log-normally distributed and compared

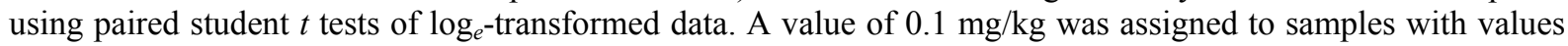
below detection limits to $\log _{e}$-transform log-normally distributed heavy metal concentrations for statistical analysis. These $\log _{e}$ means and confidence intervals were transformed back to the original scale for presentation. 
For socio-psychological data, proportions were compared using Chi-squared or Fisher's exact tests. The K6 value was analyzed using Wilcoxon rank sum tests. Generalized linear models (GLMs) with Quasipoisson errors were performed for multivariable analysis to determine risk factors associated with mental stress (high K6 value) using statistics software R version 2.14.1.

\section{Results}

\subsection{Transect of the Study Areas}

The tsunami destroyed or severely damaged all infrastructures within a few blocks of the coast in the eastern and western strata. The first floors of some housing structures located 800-1000 m inland from the coast were completely filled with sludge and debris. Many people had returned to live on the second floors of such homes by May 2011.

The ground subsided in various coastal areas of the Tohoku region after the earthquake; in Ishinomaki, the ground subsided by $1.2 \mathrm{~m}$, which was the greatest extent in Japan (Suito et al., 2011). Therefore, the lands near the coast had been covered with water pools containing sludge (Picture 3 ).

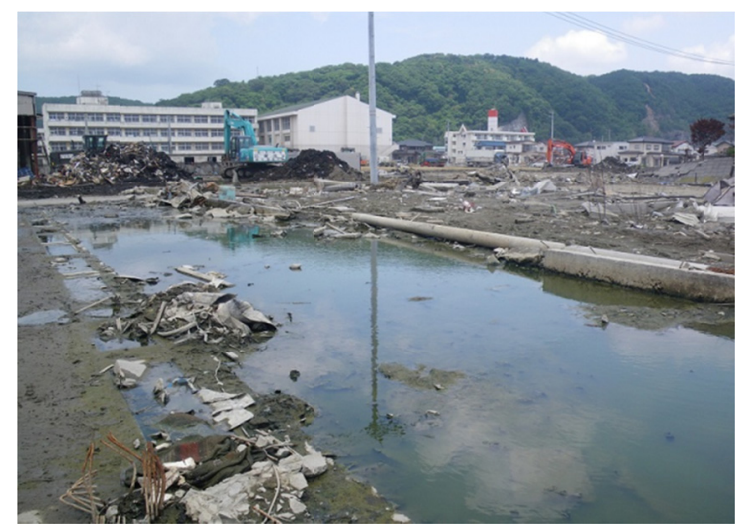

Picture 3. The residential areas near the coast covered with water containing sludge

Note: There were houses in this area before the occurrence of the tsunami (taken in June, 2011).

All the storage facilities and freezers at fish-processing factories were damaged and electricity was lost along the coast of the eastern stratum. Rotten fish from these factories were scattered on the roofs of damaged houses and in gardens throughout the areas, creating a foul odor (Picture 4).

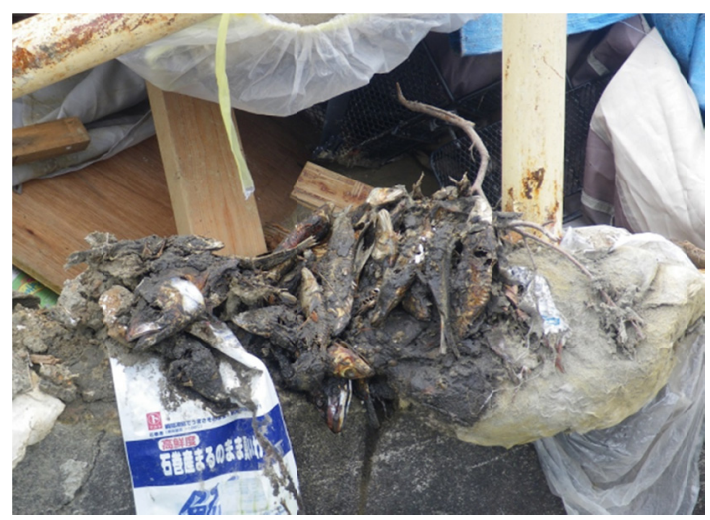

Picture 4. Rotten fish scattered in the eastern areas of the study sites (taken in June, 2011)

Disposing of marine products in the ocean is normally prohibited by law, but Miyagi Prefecture changed this policy due to the circumstances and these products were discarded into the ocean and dump sites in Yamagata Prefecture between April 11 and July 6, 2011 (Kahoku Shimpo, 2011). All storage facilities for animal feed along the coast of the western stratum were also damaged, and animal feed concentrates were scattered on the 
ground throughout the western stratum. These situations attracted innumerable flies to the ground and walls of housing structures (Picture 5).

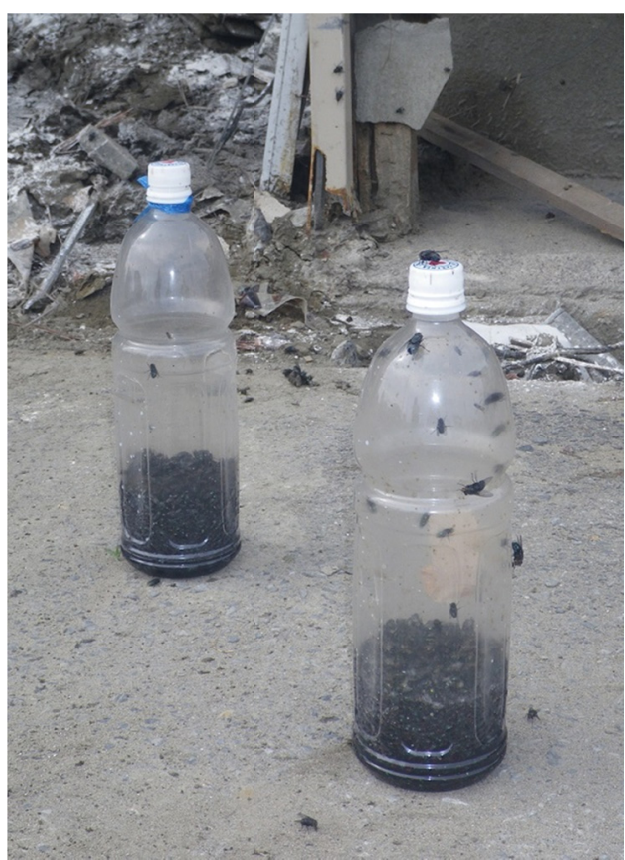

Picture 5. Meigen flies trapped by a resident using a hand-made trap containing attractant made of sugar and Japanese Sake wine (taken in June, 2011)

\subsection{Entomology}

Flies captured in a water trap in the eastern stratum in July 2011 comprised Phormia regina (Meigen) ( $\mathrm{n}=17)$, Musca domestica, and Muscina stabulans $(\mathrm{n}=1 \mathrm{each})$. Sphaeroceridae spp. are tiny flies whose size is smaller than $1 \mathrm{~mm}$ and their population in the eastern stratum was semi-quantified as,$+ 1-10$ individuals captured; ++,11-100 captured; +++, more than 101 captured. Flies in the western stratum comprised Phormia regina (Meigen) ( $\mathrm{n}=3)$; Musca domestica $(\mathrm{n}=28)$, and Muscina stabulans $(\mathrm{n}=10)$, and the density of Sphaeroceridae spp. was +++. Phormia regina (Meigen) were dominant in the eastern stratum, where fish carcasses were scattered, as this species favors protein, whereas Muscidae, which favor carbohydrates, dominated in the western stratum, where animal feed concentrates were scattered. Sphaeroceridae spp. were particularly evident in pools of water containing sludge in the western stratum. The complete disposal of marine products, removal of sludge, and spraying the area with insecticides remarkably reduced the number of flies by August 2011.

\subsection{Rodents}

Rodent traps were set in all the 20 sampling units during August 2011; only one A. speciosus was trapped in the sampling unit 17, which was close to the Kitakami canal (Figure 1). One A. speciosus was captured again at the same site in November 2011. In March 2012, two Mus musculus were captured in unit 17. In May 2012, one A. speciosus and four M. musculus were captured at the same site. In November 2012, traps set at the same site, unit 17 , as well as in the pine woods along the coast in the eastern stratum near sampling unit 9 caught eight and 23 M. musculus, respectively. The log number of rodents captured in these two units (units 9 and 17) significantly increased over time (slope $=0.08, p=0.005$ ).

\subsection{Microbiological Tests}

Table 2 shows the $\log _{10}$ of the number of colony-forming units (CFU) per $\mathrm{mL}$ of total bacteria and the number of enterobacteriaceae, Bacillus spp., and Clostridium spp. in surface water and sludge samples collected in July 2011, August 2011, and August 2012. The numbers of samples were not 20, because some units lacked surface water or sludge. Samplings for microbiology were conducted by two independent teams. The samples collected by Team A were served for total bacteria, enterobacteriaceae, Vibrio and Aeromonas, although the numbers of samples slightly differ due to the insufficient quantities. The samples collected by Team B were tested for Bacillus spp. and Clostridium spp. In July and August 2011, water samples were not collected by Team A at six units $(2,3,5,6,9$ and 20). Team B could not collect water samples at eight units $(2,3,5,6,9,12,19$ and 20) in 
July 2011, and at three units (3, 9 and 12) in August 2011. Sludge samples were not collected by Team A at five units $(3,5,6,9$ and 20) in July 2011 and at five units (3, 5, 6, 9 and 13) in August 2011. Sludge samples were not collected by Team B at nine units $(2,3,5,6,9,12,14,19$ and 20) in July 2011 and at five units $(3,7,9,12$ and 19) in August 2011. These areas had been cleaned up and improved further by August 2012 and water samples could not be collected from 11 units (1-4, 6-9, and 12-14) and sludge samples at slightly different 11 units (1, 3-6, 9, 12-14, and 19-20).

The density of enterobacteriaceae and Clostridium in surface water samples significantly decreased (3.4 to 2.7, $p$ $=0.006$ and 3.3 to 2.7 mean $\log _{10} \mathrm{CFU} / \mathrm{mL}, p=0.023$, respectively) between July and August 2011. In contrast, the total bacterial count (5.4 to 6.3 mean $\log _{10} \mathrm{CFU} / \mathrm{mL}, p<0.001$ ) and the density of enterobacteriaceae (4.4 to 4.9, $p=0.046$ ) in sludge significantly increased between July and August 2011. The concentrations of Bacillus (mean $\log _{10} \mathrm{CFU} / \mathrm{ml}: 4.9$ to $3.8, p<0.001$ ) and Clostridium (5.0 to $4.5, p=0.004$ ) significantly decreased between August 2011 and August 2012. Salmonella was not identified in any of the water or sludge samples. The prevalence of Clostridium perfringens in water samples was not significantly different between July (3/12, 25\%) and August $2011(2 / 17,11.8 \%, p=0.62)$, or between August 2011 and August $2012(2 / 9,22.2 \%, p=0.59)$. The prevalence in sludge samples was also not significantly different between July $(4 / 11,36.4 \%)$ and August $2011(5 / 15,33.3 \%, p=1.0)$, or between August 2011 and August $2012(5 / 9,55.6 \%, p=0.4)$.

Flies carried high numbers of bacteria; the mean $\log _{10} \mathrm{CFU} / \mathrm{mL}$ of total bacteria was 8.7 (95\%CI: 7.3-10.1) and that of enterobacteriaceae was 8.0 (95\%CI: 6.6-9.5, data not shown).

Table 2. $\log _{10} \mathrm{CFU} / \mathrm{ml}$ and $95 \%$ confidence interval of total bacteria, enterobacteriaceae, Bacillus spp. and Clostridium spp. in surface water and sludge

\begin{tabular}{|c|c|c|c|c|}
\hline & Jul 2011 & Aug 2011 & Aug 2012 & Statistics \\
\hline \multicolumn{5}{|l|}{ Surface water } \\
\hline Total bacteria & $\begin{array}{l}3.7(3.2-4.2) \\
(n=14)\end{array}$ & $\begin{array}{l}3.4(3.0-3.8) \\
(n=14)\end{array}$ & & $t=0.7, \mathrm{df}=13, p=0.5$ \\
\hline Enterobacteriaceae $^{\mathrm{a}}$ & $\begin{array}{l}3.4(2.9-3.9) \\
(n=14)\end{array}$ & $\begin{array}{l}2.7(2.1-3.4) \\
(n=14)\end{array}$ & & $t=3.3, \mathrm{df}=13, p=0.006$ \\
\hline \multirow[t]{2}{*}{ Bacillus spp. } & $\begin{array}{l}3.2(2.6-3.8) \\
(\mathrm{n}=12)\end{array}$ & $\begin{array}{l}2.7(1.9-3.5) \\
(n=17)\end{array}$ & $\begin{array}{l}3.1(1.4-4.1) \\
(n=9)\end{array}$ & $\begin{array}{l}\text { Jul - Aug 2011: } t=0.9 \\
\mathrm{df}=11, p=0.38\end{array}$ \\
\hline & & & & $\begin{array}{l}\text { Aug 2011- Aug 2012: } \\
t=-0.87, \mathrm{df}=8, p=0.41\end{array}$ \\
\hline \multirow[t]{2}{*}{ Clostridium spp. ${ }^{\mathrm{a}}$} & $\begin{array}{l}3.3(2.6-4.1) \\
(n=12)\end{array}$ & $\begin{array}{l}2.7(2.0-3.4) \\
(n=17)\end{array}$ & $\begin{array}{l}3.6(2.4-4.7) \\
(n=9)\end{array}$ & $\begin{array}{l}\text { Jul- Aug 2011: } t=2.6 \\
\mathrm{df}=11, p=0.023\end{array}$ \\
\hline & & & & $\begin{array}{l}\text { Aug 2011- Aug 2012: } \\
t=-1.28, \mathrm{df}=8, p=0.24\end{array}$ \\
\hline \multicolumn{5}{|l|}{ Sludge } \\
\hline Total bacteria $^{a}$ & $\begin{array}{l}5.4(4.9-5.9) \\
(n=15)\end{array}$ & $\begin{array}{l}6.3(5.9-6.6) \\
(n=15)\end{array}$ & & $t=-4.4, \mathrm{df}=14, p<0.001$ \\
\hline Enterobacteriaceae $^{\mathrm{a}}$ & $\begin{array}{l}4.4(3.8-4.9) \\
(n=15)\end{array}$ & $\begin{array}{l}4.9(4.4-5.4) \\
(n=15)\end{array}$ & & $t=-2.2, \mathrm{df}=14, p=0.046$ \\
\hline \multirow[t]{2}{*}{ Bacillus spp. ${ }^{\mathrm{b}}$} & $\begin{array}{l}5.1(3.6-6.6) \\
(n=11)\end{array}$ & $\begin{array}{l}4.9(3.8-6.1) \\
(n=15)\end{array}$ & $\begin{array}{l}3.8(3.4-4.3) \\
(\mathrm{n}=9)\end{array}$ & $\begin{array}{l}\text { Jul-Aug 2011: } t=0.18 \\
\mathrm{df}=9, p=0.86\end{array}$ \\
\hline & & & & $\begin{array}{l}\text { Aug 2011- Aug 2012: } \\
t=5.3, \mathrm{df}=10, p<0.001\end{array}$ \\
\hline \multirow[t]{2}{*}{ Clostridium spp. ${ }^{\mathrm{b}}$} & $\begin{array}{l}6.2(4.9-7.5) \\
(n=11)\end{array}$ & $\begin{array}{l}5.0(3.9-6.1) \\
(n=15)\end{array}$ & $\begin{array}{l}4.5(4.3-4.8) \\
(n=9)\end{array}$ & $\begin{array}{l}\text { Jul-Aug 2011: } t=1.8 \\
\mathrm{df}=9, p=0.11\end{array}$ \\
\hline & & & & $\begin{array}{l}\text { Aug 2011- Aug 2012: } \\
t=3.7, \mathrm{df}=10, p=0.004\end{array}$ \\
\hline
\end{tabular}

a: significantly different between July and August 2011

b: significantly different between August 2011 and August 2012

Table 3 shows the prevalence of Vibrio spp. and Aeromonas hydrophila in surface water and sludge samples. The numbers of samples are different from those in Table 2 because a different team collected the samples. One extra surface water sample was collected in August 2011. Although $V$. cholerae were isolated, they were not 
highly pathogenic serotypes $\mathrm{O} 1$ or $\mathrm{O} 139$ and none had the $\operatorname{ctx} A$ gene which is associated with virulence. The prevalences of $V$. cholerae, $V$. fluvialis, and $A$. hydrophila were not significantly different.

Table 3. Prevalence of Vibrio spp. and Aeromonas hydrophila

\begin{tabular}{llll}
\hline & July 2011 & August 2011 & $p$-value \\
\hline Surface water & $\mathrm{n}=13$ & $\mathrm{n}=14$ & \\
Vibrio cholerae* $_{\text {Vibrio fluvialis }}$ & $3(23.1 \%)$ & $3(21.4 \%)$ & 1 \\
Aeromonas hydrophila & $1(7.7 \%)$ & $3(21.4 \%)$ & 0.60 \\
Sludge & $1(7.7 \%)$ & $4(28.6 \%)$ & 0.33 \\
Vibrio cholerae* & $\mathrm{n}=12$ & $\mathrm{n}=12$ & \\
Vibrio fluvialis & $3(25.0 \%)$ & $3(25.0 \%)$ & 1 \\
Aeromonas hydrophila & $4(33.3 \%)$ & $4(33.3 \%)$ & 1 \\
\hline
\end{tabular}

*Highly pathogenic $V$. cholerae serotype $\mathrm{O} 1$ or $\mathrm{O} 139$ was not detected. None of $V$. cholerae had ctxA gene which is associated with the virulence.

Virological tests in July 2011 detected an HEV monoclonal band in one of 12 samples of sludge, but in none of 13 samples of surface water. Norovirus was not detected in any water or sludge samples in July 2011. Virological tests for water and sludge were not conducted in August 2011. Bornaviruses were undetectable in rodents sampled in July 2011.

\subsection{Chemical Analysis}

Table 4 shows changes over time in mean ion concentrations between July and August 2011. In July, the mean ratio of sample $\mathrm{Na}^{+} / \mathrm{Cl}^{-}$to seawater $\mathrm{Na}^{+} / \mathrm{Cl}^{-}$was 1.01 (95\%CI: 0.78-1.30) and the composition of the sampled surface water was similar to that of seawater. The surface water with similar composition to seawater was geographically evenly distributed in the studied areas (black dots in Figure 2A). In August 2011, the concentration of $\mathrm{Na}^{+}$remained $(p=0.65)$ but that of $\mathrm{Cl}^{-}$significantly decreased $(p=0.007)$, which resulted in a significant increase in the ratio of sample $\mathrm{Na}^{+} / \mathrm{Cl}^{-}$to seawater $\mathrm{Na}^{+} / \mathrm{Cl}^{-}(2.61, p=0.007)$. The composition of surface water had considerably changed in all tested areas by August 2011 (Figure 2B).

Table 4. Changes of the mean ion concentrations $(\mathrm{mg} / \mathrm{L})$ and $95 \%$ confidence intervals in surface water between July and August 2011

\begin{tabular}{|c|c|c|c|}
\hline & July $(\mathrm{n}=11)$ & August ( $\mathrm{n}=12$ ) & Statistics \\
\hline $\mathrm{Na}^{+}$ & $212(50-894)$ & $227.4(67.2-769.3)$ & $t=0.49, \mathrm{df}=4, p=0.65$ \\
\hline $\mathrm{NH}_{4}^{+}$ & $1.0(0.2-4.7)$ & $4.1(0.8-21.1)$ & $t=-0.06, \mathrm{df}=4, p=0.96$ \\
\hline $\mathrm{Cl}^{-}$ & $376(89-1593)$ & $156(39-629)$ & $t=3.0, \mathrm{df}=4, p=0.04$ \\
\hline $\mathrm{Na}^{+} / \mathrm{Cl}^{-}$ & $0.56(0.44-0.73)$ & $1.46(1.07-2.00)$ & $t=-5.2, \mathrm{df}=4, p=0.007$ \\
\hline $\begin{array}{l}\text { Ratio of sample and } \\
\text { seawater } \mathrm{Na}^{+} / \mathrm{Cl}^{-*}\end{array}$ & $1.01(0.78-1.30)$ & $2.61(0.32-3.58)$ & $t=-5.2, \mathrm{df}=4, p=0.007$ \\
\hline
\end{tabular}

*Seawater $\mathrm{Na}^{+} / \mathrm{Cl}^{-}(0.56)$ was calculated using the values in Sverdrup et al. (1961) 

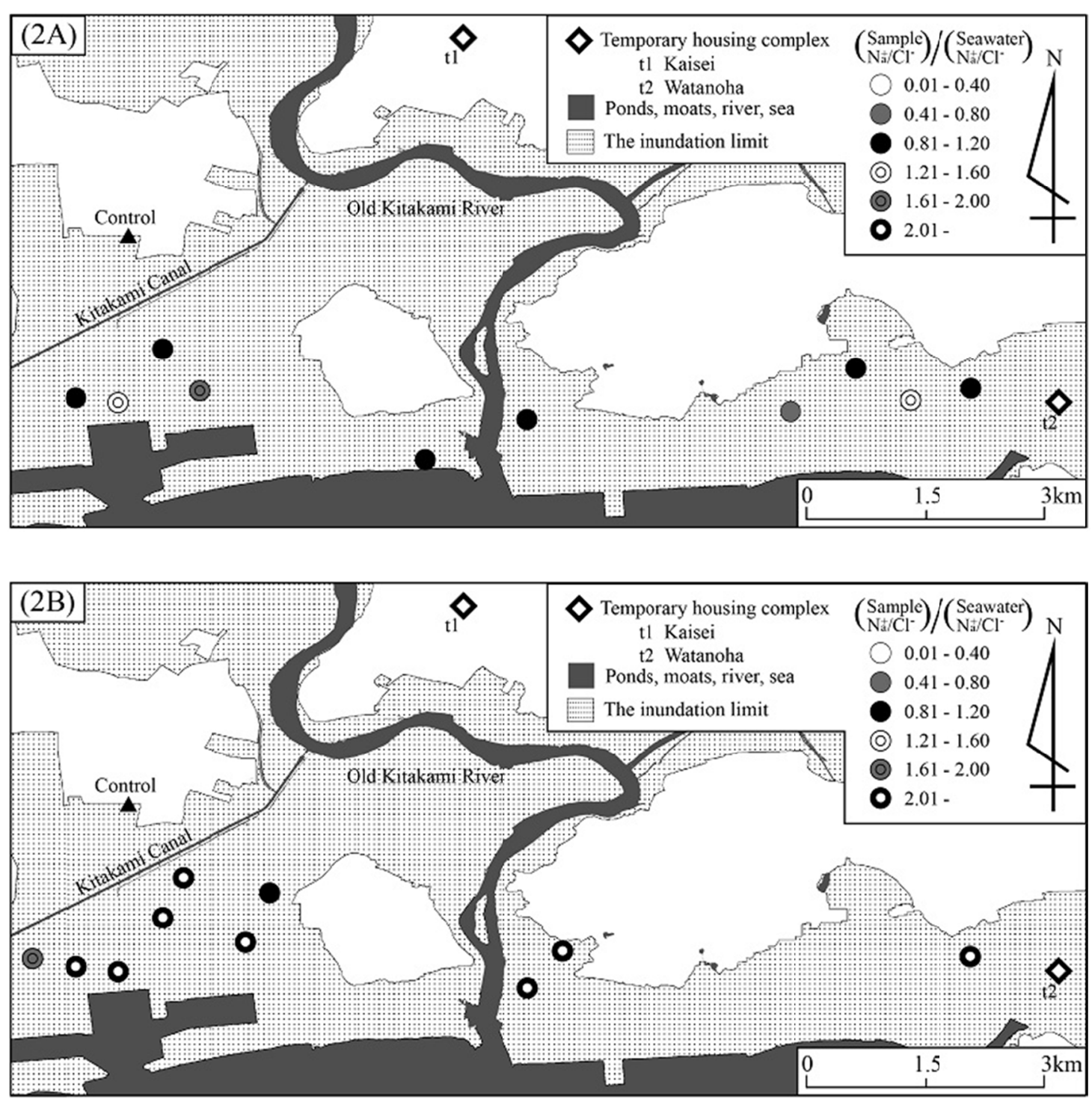

Figure 2. Geographical representation of the ratio of sample and seawater $\mathrm{Na}^{+} / \mathrm{Cl}^{-}$in July and August 2011

Note: 2A shows the map of July 2011 and 2B August 2011.

The concentration of $\mathrm{NH}_{4}{ }^{+}$did not significantly increase between July and August 2011. However, the maximum $\mathrm{NH}_{4}{ }^{+}$concentration increased from 21 in July to 173 in August 2011 (data not shown). The $\mathrm{NH}_{4}{ }^{+}$concentrations were higher in the damaged residential areas of the western stratum (Figures $3 \mathrm{~A}$ and $\mathrm{B}$ ). Both months included surface water with an $\mathrm{NH}_{4}{ }^{+}$concentration below detection limit, $0.10 \mathrm{mg} / \mathrm{L}$, and the proportions $(4 / 11(36.4 \%)$ in July and 2/12 (16.7\%) in August) were not significantly different $(p=0.37)$. 

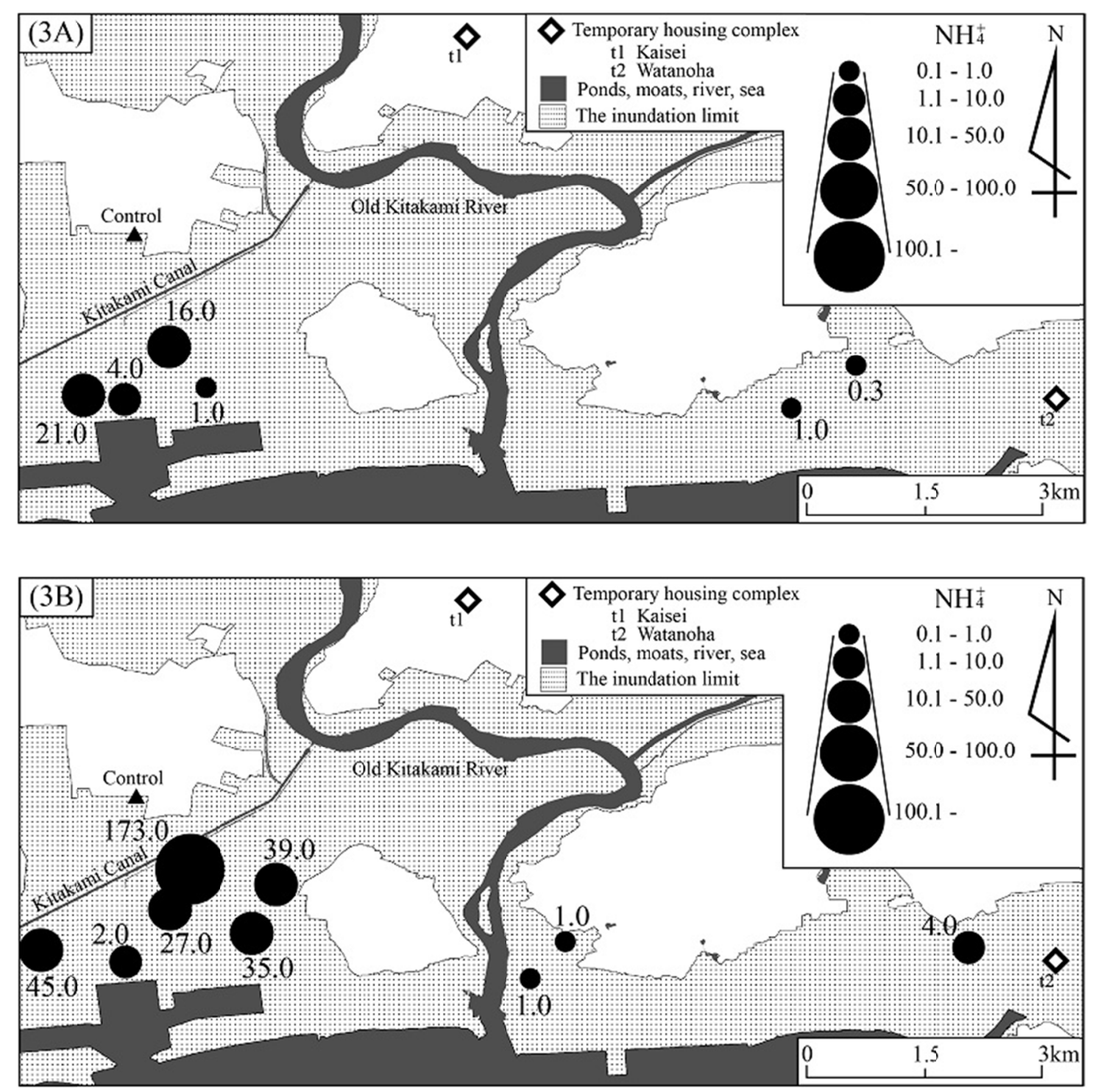

Figure 3. Geographical representation of the $\mathrm{NH}_{4}^{+}$concentrations (mg/L) in July and August 2011

Note: 3A shows the map of July 2011 and 3B August 2011.

Table 5 shows mean heavy metal concentrations in July and August 2011. The detection limit of Cd is $20 \mathrm{mg} / \mathrm{kg}$ by PIXE and $\mathrm{Cd}$ was undetectable in all samples. The concentrations of $\mathrm{Cu}, \mathrm{Hg}, \mathrm{Pb}, \mathrm{Ni}$ and $\mathrm{As}$ did not significantly differ between July and August 2011. The standard levels defined in the Soil Contamination Countermeasures Act in Japan for $\mathrm{Cd}, \mathrm{Hg}, \mathrm{Pb}$ and $\mathrm{As}$ are $150,15,150$ and $150 \mathrm{mg} / \mathrm{kg}$, respectively, and those for $\mathrm{Cu}$ and $\mathrm{Ni}$ are not stipulated (Ministry of Environment, 1991). The means and confidence intervals of $\mathrm{Cd}, \mathrm{Hg}$, $\mathrm{Pb}$, and As did not exceed these levels. However, in July 2011, one sample in unit 1 of the eastern stratum (Figure 1) contained $24.9 \mathrm{mg} / \mathrm{kg}$ of $\mathrm{Hg}$, which did exceed the standard level. Levels of $\mathrm{Pb}$ and As did not exceed standard values in all samples. In a control soil sample (Figure 1), $\mathrm{Hg}$ was undetectable and the concentrations of $\mathrm{Cu}, \mathrm{Pb}, \mathrm{Ni}$, and As were 119, 87.5, 85.3, and $2.3 \mathrm{mg} / \mathrm{kg}$, respectively. 
Table 5. Changes of the mean heavy metal concentrations $(\mathrm{mg} / \mathrm{kg})$ and $95 \%$ confidence intervals in sludge between July and August 2011

\begin{tabular}{llll}
\hline & July $(\mathrm{n}=11)$ & August $(\mathrm{n}=17)$ & Statistics \\
\hline Cadmium $(\mathrm{Cd})^{*}$ & $<20$ & $<20$ & Not applicable \\
Cupper $(\mathrm{Cu})$ & $23.5(7.1-78.1)$ & $30.0(13.1-68.8)$ & $t=-1.1, \mathrm{df}=8, p=0.30$ \\
Mercury $(\mathrm{Hg})$ & $0.6(0.1-2.4)$ & $0.4(0.1-0.9)$ & $t=-0.2, \mathrm{df}=8, p=0.83$ \\
Lead $(\mathrm{Pb})$ & $47.0(32.9-61.1)$ & $66.1(46.4-85.8)$ & $t=-2.1, \mathrm{df}=8, p=0.07$ \\
Nickel $(\mathrm{Ni})$ & $14.8(3.1-71.1)$ & $27.7(9.6-80.3)$ & $t=-1.9, \mathrm{df}=8, p=0.10$ \\
Arsenic $(\mathrm{As})$ & $3.9(0.8-19.2)$ & $7.5(3.3-17.2)$ & $t=-1.1, \mathrm{df}=7, p=0.33$ \\
\hline
\end{tabular}

*Detection limit of $\mathrm{Cd}$ is $20 \mathrm{mg} / \mathrm{kg}$ and $\mathrm{Cd}$ was not detected from all the samples.

\subsection{Socio-Psychological Situation in Temporary Housing Complexes}

\subsubsection{Qualitative Findings}

According to the qualitative records collected from the RGU students during volunteer activities, the contents of stress dynamically changed over time. Shocks due to having lost homes, jobs, family, and friends were prevalent among those living in disaster shelters and damaged houses in May 2011. Many people felt guilty for not having died themselves, considering those who had died. The amounts of debris and sludge were overwhelming, but joint cleaning activities with volunteers offered a distraction. Long waiting list to enter in a room in the temporary housing complexes and inconvenience of many of the complexes due to the remote locations induced stress in May and June. Lost community function due to the absence or relocation of community leaders and board members was a huge obstacle for those who returned to damaged homes, where they lived without basic supplies including food, clothing, and hygiene products.

According to the participatory appraisals, in September 2012 the focus of mental stress shifted to the imminent future. Several political leaders announced closing dates of the temporary housing complex, but in reality, planning, upland reclamation, housing construction, and policy support for the relocation of evacuees were delayed. Obstacles for elderly respondents included ineligibility for loans to construct houses. Even middle-aged individuals worried about how to pay for a second loan while still paying original loans for homes that were destroyed by the tsunami.

\subsubsection{Questionnaire Results}

In September 2012, 44 evacuees in the two temporary urban housing complexes and 16 in the rural complex responded to the questionnaire. The urban and rural response rates were $44 \%(44 / 100)$ and $36.4 \%(16 / 44)$, respectively, and the mean ages of respondents were 63.6 and 58.7 years, respectively. The urban relocation area planned by the authorities was inland Ishinomaki and only $30.6 \%(11 / 36)$ of the respondents wished to return to their own homes in urban areas, whereas $64.2 \%(9 / 14)$ of those in rural areas wished to return $\left(x^{2}=3.48, \mathrm{df}=1\right.$; $p=0.06)$. Regardless the planned destination either original home or inland, $46.2 \%(12 / 26)$ of urban respondents felt that their wish would be unable to be realized and 58.3\% (7/12) of these stated that financial problems were the main obstacle. Those in rural areas who chose relocation $(35.8 \%, 5 / 14)$ wished to move to nearby residential areas with higher elevation after development of these areas by the authorities, and wished to continue working in the fishing industry. All of the respondents in the rural housing complex felt that this would be realized.

High K6 value which suggests SMI (K6 value > 13) was found in 15.9\% (7/44) and 6.3\% (1/16) of the urban and rural respondents, respectively. A total of $13.3 \%(8 / 60)$ had severe mental health conditions. This was higher than the prevalence of K6 above 13 at pre-tsunami status, 5\% in 2010 (NCNP, 2013). The proportions were not significantly different between urban and rural respondents $(p=0.7)$. Table 6 shows univariate analysis of K6 values which indicate mental stress. Statistical significance was found in health problems $(p<0.001)$, lack of friends $(p=0.003)$ or trusted person to counsel $(p=0.005)$, not participating in events $(p=0.02)$, and pest infestation $(p=0.03)$. The overall mean K6 value was 6.5 (data not shown). Multivariable analysis revealed that risk factors for a high K6 value were a lack of friends $(p=0.011)$ or trusted person to counsel $(p=0.003)$ and the illness of the respondent or a family member $(p=0.003$, Table 7). 
Table 6. Univariate analysis for mental health

\begin{tabular}{|c|c|c|c|c|c|}
\hline Factors & Attributes & Sample & Percentage (\%) & K6 & $p$-value \\
\hline \multirow[t]{2}{*}{ Sex } & Male & 27 & 48.2 & 6.1 & 0.19 \\
\hline & Female & 29 & & 7.8 & \\
\hline \multirow[t]{2}{*}{ Age } & $>=65$ & 28 & 50.0 & 6.0 & 0.99 \\
\hline & $<65$ & 28 & & 7.3 & \\
\hline \multirow{2}{*}{$\begin{array}{l}\text { Health problem of the } \\
\text { respondent or family }\end{array}$} & Exist & 26 & 52.0 & 3.0 & $<0.001$ \\
\hline & Not exist & 24 & & 9.9 & \\
\hline Friends in the housing & Exist & 42 & 72.4 & 5.0 & 0.003 \\
\hline Complex & Not exist & 16 & & 10.6 & \\
\hline Trusted person to counsel & Exist & 29 & 56.9 & 3.3 & 0.005 \\
\hline in the housing complex & Not exist & 22 & & 10.9 & \\
\hline \multirow[t]{2}{*}{ Participation in events } & Participate & 43 & 75.4 & 5.4 & 0.02 \\
\hline & Not participate & 14 & & 10.2 & \\
\hline Activities to relieve & Have & 23 & 38.3 & 5.6 & 0.7 \\
\hline Stress & Do not have & 37 & & 7.1 & \\
\hline \multirow[t]{2}{*}{ Room mate } & Exist & 42 & 75.0 & 5.4 & 0.5 \\
\hline & Not exist & 14 & & 7.0 & \\
\hline \multirow[t]{2}{*}{ Children } & Exist & 6 & 10.5 & 9.0 & 0.1 \\
\hline & Not exist & 51 & & 6.8 & \\
\hline \multirow[t]{2}{*}{ Income } & Have & 7 & 12.7 & 6.5 & 0.7 \\
\hline & Do not have & 48 & & 6.7 & \\
\hline \multirow[t]{2}{*}{ Level of urbanization } & Urban & 44 & 73.3 & 5.9 & 0.7 \\
\hline & Rural & 16 & & 10.0 & \\
\hline \multirow[t]{2}{*}{ Pest infestation } & Exist & 20 & 34.5 & 9.2 & 0.03 \\
\hline & Not exist & 38 & & 5.2 & \\
\hline Satisfaction from the & Satisfied & 22 & 39.3 & 5.2 & 0.3 \\
\hline Environment & Not satisfied & 34 & & 8.0 & \\
\hline \multirow[t]{2}{*}{ Land of origin } & Ishinomaki & 46 & 76.7 & 7.0 & 0.6 \\
\hline & Other place & 14 & & 4.5 & \\
\hline
\end{tabular}

*Note: total numbers of answer are different between the questions because of the answers not provided.

Table 7. Maltivariable analysis for mental health

\begin{tabular}{llll}
\hline Factors & Estimate & Standard error & $p$-value \\
\hline Health problem of the respondent or family member & 0.92 & 0.30 & 0.011 \\
Existence of trusted person to counsel in the housing complex & -0.58 & 0.22 & 0.003 \\
Existence of friends in the housing complex & -0.79 & 0.28 & 0.003 \\
\hline
\end{tabular}

Table 8 compares associations between human relationships and mental stress in urban and rural areas. Respondents with friends in the temporary urban housing complexes had significantly lower K6 values, indicating less mental stress (4.9 vs. $11.9 ; p<0.001)$ than those without friends, whereas these values did not significantly differ in the rural complex $(5.4$ vs. $1.0, p=0.4)$. Smilarly, K6 values were significantly lower among respondents in urban areas with trusted person to counsel than without $(4.1 \mathrm{vs.} 12.7, p=0.002)$, but did not significantly differ in the rural respondents ( 3.3 vs. $6.2, p=0.8$ ). The proportions of respondents with friends $(p=0.2)$ and trusted counselors $(p=1)$ did not significantly differ between the urban and rural complexes. 
Table 8. Comparison of the associations between human relationships and mental stress (K6) in urban and rural areas

\begin{tabular}{llllll}
\hline Factors & Attributes & Sample & Percentage (\%) & K6 & $p$-value \\
\hline Friends in the complex & & & & & \\
Urban & Exist & 29 & 67.4 & 4.9 & $<0.001$ \\
& Not exist & 14 & & 11.9 & \\
Rural & Exist & 13 & 86.7 & 5.4 & 0.4 \\
& Not exist & 2 & & 1.0 & \\
Trusted person to counsel & & & & & \\
Urban & Exist & 21 & 56.8 & 4.1 & 0.002 \\
& Not exist & 16 & & 12.7 & \\
Rural & Exist & 8 & 57.1 & 3.3 & 0.8 \\
& Not exist & 6 & & 6.2 & \\
\hline
\end{tabular}

*Note: total numbers of answer are different between the questions because of the answers not provided.

\section{Discussion}

The present study revealed the temporal dynamics of environmental health risks and socio-psychological status in areas of Ishinomaki affected by the tsunami between 2011 and 2012 . While public health interests might focus on monitoring the incidence of infectious diseases, public health risks must be understood from the environmental viewpoint of tsunami-affected areas for mid- and long-term reconstruction planning. Japan has been promoting the relocation of residential areas to uplands to avoid future tsunami-related disasters (Reconstruction Agency, 2013). On the other hand, the present study showed that some populations would prefer to live in their original locations. The present environmental and socio-psychological risk assessment is important in providing real-time information to policy makers in Ishinomaki so that they can plan adequate policy support for those who lived in the tsunami-affected areas, as well as those in temporary housing complexes in Ishinomaki.

Common health problems that arose in the disaster shelters comprised respiratory and gastro-intestinal (GI) syndromes (IASR, 2011b). Norovirus infections were reported in Fukushima (IASR, 2011c) and Iwate Prefectures (IASR, 2011b). However, none of these outbreaks were large-scale considering the reported epidemic patterns (IASR, 2011b; ISAR, 2011c) and there might not be many spill-over infections from the environment, except for infections that developed during phases 1 and 2, when clean water was scarce under crowded conditions (Ueda et al., 2012). The risk of food poisoning was high in the affected areas due to the contamination of water, sludge, and flies with potentially hazardous bacteria. The disposal of fish carcasses, cleaning, and insecticide spraying dramatically decreased the number of flies, which adequately decreased health risks by August 2011.

Cholera frequently occurs during natural disasters. The global attack rate of $V$. cholerae $\mathrm{O} 1 \mathrm{Cholera}$ epidemic in Haiti after the 2010 earthquake and hurricanes was 488.9/10,000 inhabitants and the mortality rate was 6.2/10,000 inhabitants (Gaudart et al., 2013). Although $V$. cholerae and V. vulnificus was isolated in Ishinomaki, toxigenic $V$. cholerae was not. However in the USA, environmentally acquired $V$. vulnificus, $V$. parahaemolyticus, and non-toxigenic $V$. cholerae caused infections and deaths soon after Hurricane Katrina (CDC, 2005). This suggests that the bacteria isolated in Ishinomaki could have caused infections and deaths. Early establishment of hygiene in the disaster shelters and relocation to temporary housing complexes might have prevented such outbreaks. Vibrio outbreak associated with the tsunami has not been reported in any of the affected areas of Japan. After the 2004 tsunami in Banda Aceh, Indonesia, acute jaundice potentially due to infection with water-borne hepatitis A (HA) and E was identified among displaced population (WHO, 2005). The present study detected HEV in only one sample and no outbreak occurred, probably because HA and HE are not endemic in Japan. Although the land in areas affected by the tsunami remained covered with seawater until July 2011, and the $\mathrm{NH}_{4}{ }^{+}$concentration suggested high urine contamination, hygiene at the disaster shelters in the flooded areas might have been maintained at a high enough level to avoid such waterborne outbreaks. On the other hand, the high $\mathrm{NH}_{4}{ }^{+}$concentration suggested a harsh living condition of the people remained in the damaged houses, who were later relocated to temporary housing complexes or restored toilet facilities. The 
increase of the $\mathrm{Na}^{+} / \mathrm{Cl}^{-}$ratio was probably due to $\mathrm{Na}^{+}$sorption onto soil's clay particles, while $\mathrm{Cl}^{-}$was leached by rainfall. Evacuees in the disaster shelters and damaged houses were relocated to temporary housing complexes by October 11, 2011, when they were finally released from an overcrowded, uncomfortable environment.

The most dynamic changes observed in the present study were in rodent populations. After the affected areas were cleaned and debris was removed, the original residential areas became covered with grass and the lands became favorable to rodents. These animals are recognized as important mammalian reservoirs of Leptospira spp. (Meerburg, Singleton, \& Kijlstra, 2009) and shed infectious organisms in urine throughout their lifespan (Li et al., 2013; Vinetz, 2001). Leptospirosis can be fatal and an outbreak in the Philippines after the flood in 2009 was characterized by jaundice, anuria, and hemoptysis (Amilasan et al., 2012). Leptospira was not investigated in the present study, but future environmental surveys should include diagnosing leptospirosis in rodents to understand the health risks.

Notably high level of $\mathrm{Hg}(24.9 \mathrm{mg} / \mathrm{kg})$ was observed in only one sludge sample. This might have been carried from soils beneath the sea. A study of the coast in Aomori, Iwate and Miyagi prefectures found a greater variety of heavy elements in sludge than in inland samples (Baba \& Sera, 2012). Sediments in Japanese bays contain considerable amounts of toxic heavy metals (Kabir et al., 2006). A study of hair from individuals in areas affected by the tsunami in Iwate Prefecture did not find clear differences in heavy metal concentrations between before and after the tsunami (Sera et al., 2012). However, no data are available for individuals in Ishinomaki who lived in damaged houses contaminated with sludge, and the effect of exposure to heavy metal particles in dried sludge is unknown. Concentrations of $\mathrm{Cd}, \mathrm{Cr}, \mathrm{Cu}, \mathrm{Ni}$, and $\mathrm{Pb}$ increased from 7 to 35, 141 to 617, 32 to 132 , 62 to 252 , and 11 to $144 \mathrm{mg} / \mathrm{kg}$, respectively, after the 2004 tsunami in India (Ranjan et al., 2008). Although we did not find such alarming concentrations, metal elements might be released into the ecosystem and create a threat in the event of changed geochemical status (Ranjan et al., 2008). Therefore, future monitoring, especially of agricultural lands, is recommended, as elements absorbed from agricultural products can enter the food chain.

The contents of mental stress considerably changed over time, but residents in temporary housing complexes remained highly stressed even at one and a half years after the tsunami. A published review has argued that $30-50 \%$ of individuals after a tsunami would experience moderate to severe psychological distress that might resolve with time, or mild distress that could become chronic (Carballo et al., 2005), which supports the findings in the present study. The risk factors for serious mental illness suggested that individuals without close human relationships might be vulnerable. Our comparison of associations between human relationships and mental stress in urban and rural areas also supported this assertion. Human relationships remained close in rural areas, where even those who felt isolated did not have increased mental stress. In contrast, evacuees were from many different places in urban complexes, and weaker human relationships affected mental health. A review paper which summarizes the impacts from tsunamis in the world has indicated that women, children, and elderly individuals are the most vulnerable to mental stress during a tsunami (Carballo, Heal, \& Hernandez, 2005). The present study, however, did not find such a tendency. The prevalence of mental illness among such vulnerable populations might have been higher soon after the tsunami.

\section{Conclusion}

Considering the effect of removing sludge from the soil of affected areas and the limited number of people returning to their original residences, the assessed environmental health risk has been reduced to a level that is acceptable for living. However, the population of rodents is increasing, and these pests may harbor hazards for humans. Monitoring rodent population dynamics and the prevalence of zoonotic agents such as Leptospira spp. might be needed. Financial support for evacuees to construct homes is also recommended. Furthermore, mental support is needed for evacuees in temporary housing complexes and efforts should be directed towards enhancing closer relationships in such complexes.

\section{Acknowledgements}

We would like to thank Ishinomaki City Council for the advice, help and facilitation in our collaborative activities since the very difficult time of the disaster. We also would like to thank Mitsui \& Co., Ltd Environmental Fund and RGU for research funding. Many thanks go to NPOs APCAS (Action for Peace, Capability and Sustainability), Ishinomaki Environmental Net, P-CAT (Primary Care for All) and Agarain, NGO PARCIC (Pacific Asia Resource Center Inter-Peoples Cooperation) and RGU student volunteer service, Raku-Net for the enthusiastic and heartfelt joint activities, advices, logistical assistance and accommodation. We thank Dr. Hajime Takahashi at RGU in March-April 2011 for the coordination with NPOs. Professional advices on psychiatry were provided by Dr. Michiko Watari at the National Center for Psychiatry and Neurological Research, Japan. We thank Miyagi Prefecture Furukawa Agriculture Research Institute for the discussions on 
comparative data on heavy metal concentration in unaffected soil by tsunami. The inundation limit spatial data was produced by the Earth Environmental Engineering Group, Institute of Industrial Science, the University of Tokyo, under permission by the Geospatial Information Authority of Japan. The biggest thanks and our love go to the people in Ishinomaki participated in this study as well as all those who were affected by the Great East Japan Earthquake. We shall never forget about the victims of the disaster.

\section{References}

Aghababian, R. V., \&Teuscher, J. (1992). Infectious diseases following disease emergencies in disasters. Annals of Emergency Medicine, 21, 4. http://dx.doi.org/10.1016/S0196-0644(05)82651-4

Amilasan, A. T., Ujiie, M., Suzuki, M., Salva, E., Belo, M. C. P., Koizumi, N., ... Ariyoshi, K. (2012). Outbreak of leptospirosis after flood, the Philippines, 2009. Emerging Infectious Diseases, 18(1), 91-94. http://dx.doi.org/10.3201/eid1801.101892

Baba, F., \& Sera, K. (2012). Analysis of contaminated sludge deposited on the land attacked by great tsunami following Tohoku Great Earthquake Disaster. International Journal of PIXE, 22(1-2), 231-39. http://dx.doi.org/10.1142/S012908351240027X

Carballo, M., Heal, B., \& Hernandez, M. (2005). Psychological aspects of the Tsunami. Journal of the Royal Society of Medicine, 98, 396-399. http://dx.doi.org/10.1258/jrsm.98.9.396

CDC. (2005). Vibrio illness after Hurricane Katrina - multiple States, August-September 2005. Morbidity and Mortality Weekly Report, September 14, 2005, 54, 1-4.

Furukawa, T., Kawakami, N., Saitoh, M., Ono, Y., Nakane, Y., Nakamura, Y., ... Kikkawa, T. (2008). The performance of the Japanese version of the K6 and K10 in the World Mental Health Survey Japan. International Journal of Methods in Psychiatric Research, 17(3), 152-158. http://dx.doi.org/10.1002/mpr.257

Gaudart, J., Rebaudet, S., Barrais, R., Boncy, J., Faucher, B., Piarroux, M., ... Piarroux, R. (2013). Spatio-temporal dynamics of cholera during the first year of the epidemic in Haiti. PLoS Neglected Tropical Diseases, 7(4), e2145. http://dx.doi.org/10.1371/journal.pntd.0002145

IASR. (2011a). Countermeasure against infectious disease outbreaks in Miyagi Prefecture after the 2011 off the Pacific coast of Tohoku Earthquake (in Japanese). Infectious Agents Surveillance Report, 32, S3-S4.

IASR. (2011b). Disaster shelter surveillance and countermeasure against infectious diseases in Iwate Prefecture (in Japanese). Infectious Agents Surveillance Report, 32, S1-S3.

IASR. (2011c). The emesis and diarrhea outbreak in a disaster shelter in Koriyama, Fukushima (in Japanese). Infectious Agents Surveillance Report, 32, S8-S9.

IDSC. (2011). Infectious disease incidence report associated with the Great East Japan Earthquake as of April $13^{\text {th }}$ 2011 (in Japanese). Japan Infectious Disease Surveillance Center.

IDSC. (2012). Infectious disease surveillance of safe shelter in Miyagi Prefecture after Tohoku earthquake (March 11, 2011) occurrence (in Japanese). Annals of Miyagi Prefecture Health and Environment Center, 30, 52-57.

Ishinomaki City. (2013). Damage situations report as of $31^{\text {st }}$ March, 2013. Information associated with Great East Japan Earthquake (in Japanese). Ishinomaki City.

JMA. (2011). The 2011 off the Pacific Coast of Tohoku Earthquake - Portal -. Japan Meteorological Agency (JMA). Retrieved from http://www.jma.go.jp/jma/en/2011_Earthquake/2011_Earthquake.html

JMA. (2013, May 14). Statistics in Ishinomaki. Japan Meteorological Agency (JMA). Retrieved from http://www.data.jma.go.jp/obd/stats/

Kabir, H. M., Narusawa, T., Nishiyama, F., \& Sumi, K. (2006). Elemental analysis of Uranouchi Bay seabed sludge using PIXE. International Journal of PIXE, 16(3-4), 221-230. http://dx.doi.org/10.1142/S012908350600099X

Kahoku Shimpo. (2011, July 7). Disposal of marine products ended. Kahoku Shimpo newspaper.

Kanai,Y., Tsujikawa, M., Yunoki, M., Nishiyama, S., Ikuta, K., \& Hagiwara, K. (2009). Long-term shedding of hepatitis $\mathrm{E}$ virus in the feces of pigs infected naturally, born to sows with and without maternal antibodies. Journal of Medical Virology, 82(1), 69-76. http://dx.doi.org/10.1002/jmv.21647 
Kessler, R. C., Barker, P. R., Colpe, L. J., Epstein, J. F., Gfroerer, J. C., Hiripi, E.,...Zaslavsky, A. M. (2003). Screening for serious mental illness in the general population. Archives of General Psychiatry, 60(2), 184-189. http://dx.doi.org/10.1001/archpsyc.60.2.184

Kishi, M., Nakaya, T., Nakamura, Y., Kakinuma, M., Takahashi, T. A., Sekiguchi, S., ... Ikuta, K. (1995). Prevalence of Borna disease virus RNA in peripheral blood mononuclear cells from blood donors. Medical Microbiology and Immunology, 184, 135-8. http://dx.doi.org/10.1007/BF00224350

Kojima, S., Kageyama, T., Fukushi, S., Hoshino, B., Shinohara, M., Uchida, K., ... Katayama, K. (2002). Genogroup-specific PCR primers for detection of Norwalk-like viruses. Journal of Virological Methods, 100, 107-114. http://dx.doi.org/10.1016/S0166-0934

Kouadio, K., Isidore, K., Aljunid, S., Kamigaki, T., Hammad, K., \& Oshitani H. (2012). Infectious disease following natural disasters: prevention and control measures. Expert Review of Anti-Infective Therapy, 10(1), 95-104. http://dx.doi.org/10.1586/eri.11.155

Li, S., Wang, D., Zhang, C., Wei, X., Tian, K., Li, X., ... Yan, J. (2013). Source tracking of human leptospirosis: serotyping and genotyping of Leptospira isolated from rodents in the epidemic area of Guizhou province, China. BMC Microbiology, 13, 75. http://dx.doi.org/10.1186/1471-2180-13-75

Lu, L., Li, C., \& Hagedorn, C. H. (2006). Phylogenetic analysis of global hepatitis E virus sequences: genetic diversity, subtypes and zoonosis. Reviews in Medical Virology, 16(1), 5-36. http://dx.doi.org/10.1002/rmv.482

Makita, K., Fèvre, E. M., Waiswa, C., Bronsvoort, M. D. C., Eisler, M. C., \& Welburn, S. C. (2010). Population-dynamics focussed rapid rural mapping and characterization of the peri-urban interface of Kampala, Uganda. Land Use Policy, 27, 888-897. http://dx.doi.org/10.1016/j.landusepol.2009.12.003.

Mariner, J. C., \& Paskin, R. (2000). Manual on Participatory Epidemiology. FAO, Agriculture and Consumer Protection Department, Rome, Italy.

Meerburg, B. G., Singleton, G. R., \& Kijlstra, A. (2009). Rodent-borne diseases and their risks for public health. Critical Reviews in Microbiology, 35(3), 221-270. http://dx.doi.org/10.1080/10408410902989837

MIAC. (2011). Population, population dynamics and households number survey based on Basic Resident Register. Ministry of Internal Affairs and Communications, Japan.

MLITT. (2011). Survey report of the Tsunami damage caused by the Great East Japan Earthquake (Third Report). A survey report on the situation of evacuation from the Tsunami Press Release on December 26, 2011. Ministry of Land, Infrastructure, Transport and Tourism. Retrieved from http://www.mlit.go.jp/common/000186474.pdf

Mitsui, T., Tsukamoto, Y., Yamazaki, C., Masuko, K., Tsuda, F., Takahashi, M., ... Okamoto, H. (2004). Prevalence of hepatitis E virus infection among hemodialysis patients in Japan: evidence for infection with a genotype $3 \mathrm{HEV}$ by blood transfusion. Journal of Medical Virology, 74(4), 563-572. http://dx.doi.org/10.1002/jmv.20215

Ministry of Environment. (1991). The standard level of Designated Hazardous Substances in soil (Table 3), The Soil Contamination Countermeasures Act, Japan Ministry of Environment.

Miyagi Prefecture. (2012). A guide book of livelihood support for the disaster victims. Retrieved from http://www.pref.miyagi.jp/uploaded/attachment/123693.pdf

NCNP. (2013, Sep 20). 2010 database of K6 from Comprehensive Survey of Living Conditions. National Information Center of Disaster Mental Health, National Center for Neurology and Psychiatry (NCNP). Retrieved from http://saigai-kokoro.ncnp.go.jp/document/medical.html

NPA. (2013). Damage situation and police countermeasures associated with 2011 Tohoku district off the Pacific Ocean Earthquake, 10 April 2013. Emergency Disaster Countermeasures Headquarters, National Police Agency (NPA) of Japan.

PMJHC. (2011, April 1). Statement by the Prime Minister Naoto Kan. Prime Minister of Japan and His Cabinet (PMJHC). Retrieve from http://www.kantei.go.jp/jp/kan/statement/201104/01kaiken.html

Ranjan, R. K., Ramanathan, A., Singh, G., \& Chidambaram, S. (2008). Assessment of metal enrichments in tsunamigenic sediments of Pichavaram mangroves, southeast coast of India. Environmental Monitoring and Assessment, 147, 389-411. http://dx.doi.org/10.1007/s10661-007-0128-y 
Reconstruction Agency. (2013). Summary of the 2013 Preliminary Budget. Retrieved from http://www.reconstruction.go.jp/topics/20130329_25zanteiyosangaiyou.pdf

Sack, D. A., Sack, R. B., Naire, G. B., \& Siddique, A. K. (2004). Cholera. Lancet, 363(9404), 223-233. http://dx.doi.org/10.1016/S0140-6736(03)15328-7

Sera, E., \& Yanagisawa, T. (1992). The Takizawa PIXE facility combined with a baby cyclotron for position nuclear medicine. International Journal of PIXE, 2(1), 47-55. http://dx.doi.org/10.1142/S0129083592000051

Sera, K., Goto, S., Takahashi, C., Saitoh, Y., \& Yamauchi, K. (2013). Effects of heavy elements in the sludge conveyed by the 2011 Tsunami on human health and the recovery of the marine ecosystem. Proceedings, the $13^{\text {th }}$ International Conference on Particle Induced X-ray emission, Gramado, Brazil, March 3-8, 2013.

Shibahara, S. (2011). The 2011 Tohoku Earthquake and Devastating Tsunami. Tohoku Journal of Experimental Medicine, 223, 305-307. http://dx.doi.org/10.1620/tjem.223.305

Staeheli, P., Sauder, C., Hausmann, J., Ehrensperger, F., \& Schwemmle, M. (2000). Epidemiology of Borna disease virus. Journal of General Virology, 81, 2123-35.

Statistics Bureau. (2011). East Japan Great Earthquake and public statistics. The $32^{\text {nd }}$ Statistics symposium. Statistics Bureau, Director-General for Policy Planning and Statistical Research and Training Institute, Japan.

Suito, H., Nishimura, T., Ozawa, S., Kobayashi, T., Tobita, M., Imakiire, T., ... Kawamoto, S. (2011). Coseismic deformation and fault model of the Pacific cost of Tohoku Earthquake, based on GEONET (in Japanese). Bulletin of the GSI, 122, 29-37.

Sverdrup, H. U., Johnson, M. W., \& Fleming, R. H. (1961). The oceans: their physics, chemistry, and general biology (Modern Asia edition), Prentice-Hall.

Ueda, S., Hanzawa, K., Shibata, M., \& Suzuki, S. (2012). High prevalence of deep vein thrombosis in Tsunami-flooded shelters established after the Great East-Japan Earthquake. Tohoku Journal of Experimental Medicine, 227, 199-202. http://dx.doi.org/10.1620/tjem.227.199

Vinetz, J. M. (2001). Leptospirosis. Current Opinion in Infectious Diseases, 14(5), 527-538. http://dx.doi.org/10.1097/00001432-200110000-00005

Vose, D. (2008). Risk Analysis - A quantitative guide (3rd Ed.). John Wiley \& Sons, Ltd. Chichester, UK.

WHO. (2005). Epidemic-prone disease surveillance and response after the tsunami in Aceh Province, Indonesia. Weekly Epidemiological Record, 80, 157-164.

Wong, D. C., Purcell, R. H., Sreenivasan, M. A., Prasad, S. R., \& Pavri, K. M. (1980). Epidemic and endemic hepatitis in India: evidence for a non-A, non-B hepatitis virus aetiology. Lancet, 2(8200), 876-879. http://dx.doi.org/10.1016/S0140-6736(80)92045-0

Yamai, S., Okitsu, T., \& Katsube, Y. (1998). Detection of Vibrio cholerae from river water. (in Japanese) Journal of the Japanese Association for Infectious Diseases, 70(12), 1234-1241.

Yoshii, T., Imamura, M., Matsuyama, M., Koshimura, S., Matsuoka, M., Mas, E., \& Jimenez, C. (2013). Salinity in soils and Tsunami deposits in areas affected by the 2010 Chile and 2011 Japan Tsunamis. Pure and Applied Geophysics, 170(6-8), 1047-66. http://dx.doi.org/10.1007/s00024-012-0530-4

\section{Copyrights}

Copyright for this article is retained by the author(s), with first publication rights granted to the journal.

This is an open-access article distributed under the terms and conditions of the Creative Commons Attribution license (http://creativecommons.org/licenses/by/3.0/). 